\title{
THE ABILITY OF CHOLESTYRAMINE RESIN AND OTHER ADSORBENTS TO BIND ESCHERICHIA COLI ENTEROTOXINS
}

\author{
N. A. Mullan, M. N. Burgess, R. J. Bywater and P. M. Newsome \\ Beecham Pharmaceuticals Research Division, Animal Health \\ Research Centre, Walton Oaks, Tadworth, Surrey KT20 7NT
}

NeOnatal diarrhoea in piglets and calves is commonly caused by colonisation of the small intestine by enteropathogenic strains of Escherichia coli. The $E$. coli strains concerned secrete a heat-labile enterotoxin (LT) and two heatstable enterotoxins (STa and STb) (Smith and Gyles, 1970; Burgess et al., 1978). STa is active in neonatal piglets and infant mice, but inactive in weaned pigs; STb is active in weaned pigs and in ligated intestinal loops of rabbits, but inactive in neonatal piglets and infant mice (Burgess et al., 1978). These toxins presumably attach to receptors on the epithelial surface and lead to excessive intestinal secretion, causing diarrhoea and dehydration.

A substance able to compete with the epithelial receptors for attachment of these enterotoxins might be expected to reduce their effect in the gut. Several pharmaceutical products containing adsorbent materials are intended to control diarrhoea by adsorbing by-products of bacterial metabolism (Martin, 1955). Kaolin has long been employed as an adsorbent in diarrhoea remedies although activated attapulgite has superior adsorptive properties (Barr and Arnista, 1957)

There is little firm evidence that these adsorbents are useful in the treatment of diarrhoea of infective origin. The present study was undertaken to evaluate some materials for their effectiveness in reducing the fluid secretion caused by STa, STb or LT.

One compound, cholestyramine, a quaternary ammonium anion-exchange resin with a high molecular weight, was highly effective in binding STa in vitro, and $\mathrm{STa}, \mathrm{STb}$ and $\mathrm{LT}$ in vivo. This compound was further studied in piglets given either enterotoxin or enteropathogenic $E$. coli.

\section{MATERIALS AND METHODS}

Experimental animals were all bred on the premises. Suckling mice were produced by a colony originally stocked with outbred MSI mice (OLAC, Oxford). Neonatal piglets and weaned pigs were mainly from pure Landrace stock. The neonatal piglets were 2 days old at the time of use.

Organisms. E. coli strains P16 (09:K103), P307 (08:K87:K88a,b) and P155 (0149:K91:K88a,c:H10) were obtained from Dr H. Williams Smith, Houghton Poultry

Received 12 Mar. 1979; accepted 29 Mar. 1979.

J. MED. MICROBJOL. - VOL. 12 (1979) 000 
Research Station, Houghton, Huntingdonshire. These strains secrete STa $+\mathrm{STb}, \mathrm{STb}+\mathrm{LT}$, and $\mathrm{STa}+\mathrm{STb}+\mathrm{LT}$ respectively.

Preparation of infective inocula. For injection into pig ligated intestinal loops, $E$. coli strain P16 from a Dorset Egg Slope (Oxoid) was inoculated into $10 \mathrm{ml}$ of peptone water and incubated at $37^{\circ} \mathrm{C}$ for $18 \mathrm{~h}$. For infection of neonatal piglets, $10 \mathrm{ml}$ of peptone water was seeded with $0 \cdot 1$ $\mathrm{ml}$ of an 18-h culture of E. coli strain P155 and incubated at $37^{\circ} \mathrm{C}$ for $6 \mathrm{~h}$. The 6-h cultures were diluted to contain $6 \times 10^{3}$ viable organisms $/ \mathrm{ml}$ before administration.

Preparation of enterotoxic inocula. Culture filtrates containing STa and STb from E. coli strain P16 were produced as previously reported (Mullan, Burgess and Newsome, 1978); the defined medium of Mitchell, Tame and Kenworthy (1974) containing $0.5 \%$ glucose was used. LT from $E$. coli strain P307 consisted of a cell-suspension lysate $(5 \% \mathrm{w} / \mathrm{v})$ prepared as described by Burgess et al. (1979).

Suckling-mouse assay for STa was performed as described by Dean et al. (1972), with modifications previously reported (Mullan et al., 1978). The response of suckling mice to culture filtrates containing STa was determined by dosing groups of six animals orally with $0 \cdot 1$ $\mathrm{ml}$ of the sample and measuring the ratio of gut weight to remaining body weight (GW:BW) $2 \mathrm{~h}$ later. A measure of the fluid secretion (FS) caused by STa was obtained by subtracting from the value obtained the GW: BW ratio of animals inoculated with physiological saline.

The amount of STa given was expressed in terms of units obtained from a dose-response curve previously reported (Mullan et al., 1978). One unit of STa was equivalent to a GW:BW ratio of $0 \cdot 105$. The reduction in FS caused by various adsorbents was calculated from the following formula.

$$
\text { Adsorbent effect }(\%)=\left(\frac{\text { FS toxin }- \text { FS adsorbent }}{\text { FS toxin }}\right) \times 100
$$

"FS toxin" was a measure of the fluid secretion caused by STa alone, and "FS adsorbent" was a measure of the fluid secretion caused by STa after reaction with adsorbent. A $100 \%$ effect indicated no FS.

Assay for STb, LT and viable organisms in ligated intestinal loops of pigs. The technique used was basically that of Smith and Halls (1967). Loops $10 \mathrm{~cm}$ in length were prepared in pigs aged 7-9 weeks, and no more than 18 loops were used in each pig. Only one type of enterotoxic material was tested in each pig. Ligated loops were inoculated in pairs. In each pair one loop received either $5 \mathrm{ml}$ of STb $+5 \mathrm{ml}$ of physiological saline (PS), $2 \mathrm{ml}$ of LT $+2 \mathrm{ml}$ of PS, or $0.2 \mathrm{ml}$ of an 18-h culture of strain P16 $+5 \mathrm{ml}$ of PS; this loop served as a positive control for the adjacent loop in which PS was replaced by PS containing $500 \mathrm{mg}$ of cholestyramine. Pigs were killed $18 \mathrm{~h}$ later and the inoculated loops were removed. The fluid content $(\mathrm{ml})$ and length $(\mathrm{cm})$ of each loop were measured and the volume-to-length ratio was calculated. The response of each treated loop was compared with the response of the positive control loop immediately proximal to it.

Piglet oral-dosing assay for STa. The method of Kohler (1968) was employed. Animals were dosed orally with $25 \mathrm{ml}$ of a filtrate containing approximately 400 units of STa and observed for diarrhoea on a 0-3 scale every hour for $7 \mathrm{~h}$; they were recorded as diarrhoeic if they produced fluid faeces for at least $1 \mathrm{~h}$. When cholestyramine was used it was mixed with the STa filtrate before administration.

Infection assay in nconatal piglets. Colostrum-deprived piglets were inoculated orally with 5 $\mathrm{ml}$ of a suspension of $E$. coli strain P155 containing $6 \times 10^{3}$ organisms $/ \mathrm{ml}$. Animals were then returned to the sow and $24-36 \mathrm{~h}$ later, when they were scouring, treatment was begun with either cholestyramine resin, amoxycillin, or both. The consistency of the faeces was scored twice daily on a $0-3$ scale for 5 days. Rectal swabs were collected at the time of treatment and from survivors at the end of the experiment. By means of antiserum to E. coli strain P155, the strain administered was identified in rectal swabs from a representative number of animals. Pigs were weighed at the time of treatment and survivors were weighed at the end of the experiment.

Reaction of adsorbents with STa in vitro. Equal volumes of culture filtrate containing STa and aqueous adsorbent suspensions were shaken at ambient temperature $\left(22^{\circ} \mathrm{C}\right)$ for $30 \mathrm{~min}$. The supernates were removed and tested for enterotoxic activity in suckling mice. When the effect of 
sow's milk on the efficacy of the adsorbent was studied, the adsorbent was suspended in an equal volume of milk.

Recovery of cholestyramine from piglets. In one experiment, after scouring piglets had been treated for 3 days, the animals were killed and the contents of the stomach, small intestine and large intestine removed and washed. Portions were then either assayed for adsorbent activity, or treated with $1 \mathrm{~N}$ sodium hydroxide and boiled and dried to constant weight to determine the amount of sodium hydroxide-insoluble material (cholestyramine).

Antibiotic therapy. Amoxycillin in an oral dose formulation (Clamoxyl, Beecham Animal Health, Brentford) was used in experiments concerned with antibiotic therapy of scouring piglets.

Adsorbents. Pharmasorb Regular and Pharmasorb Colloidal (attapulgus clay products) were obtained from Lawrence Industries, Mitcham, Surrey. The Bentone gellants were obtained from Steetley Mineral Products, Worksop, Nottinghamshire; these gellants were formed by replacing the inorganic cations of a clay mineral lattice with organic cations.

Kaolin, light B.P. was obtained from Evans Medical Ltd, Liverpool. Cholestyramine, a commercial preparation of the anion-exchange resin AG-1-X2, was marketed by Merck, Sharpe and Dohme Ltd under the trade name of Cuemid. Other ion-exchange resins were obtained from Bio-Rad Labs., Watford, Herts.

Statistics. Analysis of variance, Student's $t$ test (paired and unpaired) and linear correlation were used.

\section{RESULTS}

\section{STa adsorption in vitro}

Table I shows the adsorbent effect of various substances. After allowing each substance to react with STa in vitro, any residual enterotoxic effect was assessed in suckling mice. Neither kaolin nor attapulgite removed any of the STa activity from sterile culture filtrates of $E$. coli strain P16. Three of four modified bentone materials bound significant amounts of STa. The most effective adsorbents were the strong anion-exchange resin, AG-1-X2, and bentone 27. Both removed virtually all of the STa activity. The strong cation-exchange resin, AG-50W-X4, and the non-ionic macroreticular XAD-2 resin also bound significant amounts of STa.

\section{TABLE I}

Binding of STa to a selection of adsorbents in vitro

\begin{tabular}{l|cc}
\hline \multicolumn{1}{c|}{ Adsorbent } & $\begin{array}{c}\text { Amount }(\mu \mathrm{g}) \text { of } \\
\text { adsorbent } \\
\text { mixed with each STa } \\
\text { unit before dosing mice }\end{array}$ & $\begin{array}{c}\text { Adsorbent effect (\%) } \\
\text { (mean } \begin{array}{c}\% \\
\text { of the mean [SEM]) }\end{array}\end{array}$ \\
\hline Kaolin & $2500^{*}$ & $0 \pm 26$ \\
Non-colloidal attapulgite & $2500^{*}$ & $0 \pm 19$ \\
Colloidal attapulgite & $2500^{*}$ & $0 \pm 14$ \\
Bentone 18 & $625 \dagger$ & $34 \pm 13 \ddagger$ \\
Bentone 27 & $625 \dagger$ & $98 \pm 6 \ddagger$ \\
Bentone 34 & $625 \dagger$ & $25 \pm 4$ \\
Bentone 38 & $625 \dagger$ & $33 \pm 2 \ddagger$ \\
AG-50W-X4 & $625 \dagger$ & $39 \pm 2 \ddagger$ \\
DEAE-cellulose & $625 \dagger$ & $18 \pm 4$ \\
XAD-2 & $625 \dagger$ & $37 \pm 8 \ddagger$ \\
AG-1-X2 & $625 \dagger$ & $98 \pm 5 \ddagger$ \\
\hline
\end{tabular}

* Each suckling mouse received 2 units of STa (equivalent to a GW:BW ratio of $0 \cdot 117 \pm 0 \cdot 005$ ).

+ Each suckling mouse received 4 units of STa (equivalent to a $G W: B W$ ratio of $0 \cdot 135 \pm 0 \cdot 007$ ).

$\ddagger$ Significant reduction from control response as determined by Student's $t$ test $(\mathrm{p}=<0.05-<0.001)$. 
STa adsorption in the alimentary tract of suckling mice

The two most effective adsorbents, bentone 27 and cholestyramine resin (AG-1-X2), were evaluated in vivo. Each was administered to suckling mice at different times in relation to STa challenge. Table II shows that only cholestyramine resin bound significant amounts of STa. It was effective in reducing fluid secretion when given $40 \mathrm{~min}$. before, and up to $30 \mathrm{~min}$. after, STa challenge.

TABLE II

Administration of selected adsorbents to suckling mice at various times in relation to a dose of STa

\begin{tabular}{c|ccc}
\hline Adsorbent & $\begin{array}{c}\text { Concentration of } \\
\text { adsorbent } \\
(\mu \mathrm{g} / \text { STa unit) }\end{array}$ & $\begin{array}{c}\text { Time (minutes before } \\
\text { or after dosing with STa) } \\
\text { at which mice treated } \\
\text { with adsorbent }\end{array}$ & $\begin{array}{c}\text { Adsorbent effect } \\
(\%) \\
\text { (mean } \pm \text { SEM) }\end{array}$ \\
\hline Cholestyramine & $720^{*}$ & -40 & $95 \pm 3 \ddagger$ \\
& $720^{*}$ & 0 & $89 \pm 4 \ddagger$ \\
Bentone 27 & $720^{*}$ & +10 & $62 \pm 7 \pm$ \\
& $720^{*}$ & +20 & $48 \pm 11 \ddagger$ \\
& $720^{*}$ & -40 & $37 \pm 15$ \\
& $1100 \dagger$ & 0 & $0 \pm 8$ \\
\hline
\end{tabular}

- Each animal received 3.5 units of STa (equivalent to a GW:BW ratio of $0 \cdot 132 \pm 0.005$ ).

+ Each animal received 2.5 units of STa (equivalent to a $G W: B W$ ratio of $0 \cdot 124 \pm 0.003$ ).

$\ddagger$ Significant reduction from control response as determined by Student's $t$ test $(p<0.05-0.001)$.

\section{STa adsorption by graded concentrations of cholestyramine resin in vitro}

Twofold dilutions of cholestyramine suspension were allowed to react with equal volumes of culture filtrate containing STa. The supernates were then tested in suckling mice. The figure shows that the resin produced a reduction in fluid secretion that showed a significant linear correlation with the log concentration of cholestyramine $(r=0.999, p<0.001)$.

\section{Adsorptive effect of cholestyramine resin in pig ligated intestinal loops treated with $S T b, L T$ or viable E. coli}

The results are shown in table III. The cholestyramine resin significantly reduced the secretion caused by $\mathrm{STb}, \mathrm{LT}$ or viable $E$. coli.

\section{STa adsorption in the alimentary tract of piglets}

Cholestyramine resin was mixed with STa and administered to piglets aged 2 days. The piglets were observed for diarrhoea and compared with litter mates dosed with STa alone. In five of seven animals dosed with the mixture of resin and STa, no diarrhoea was noted and the mean diarrhoea score was significantly reduced; each of seven control piglets had diarrhoea (table IV). 


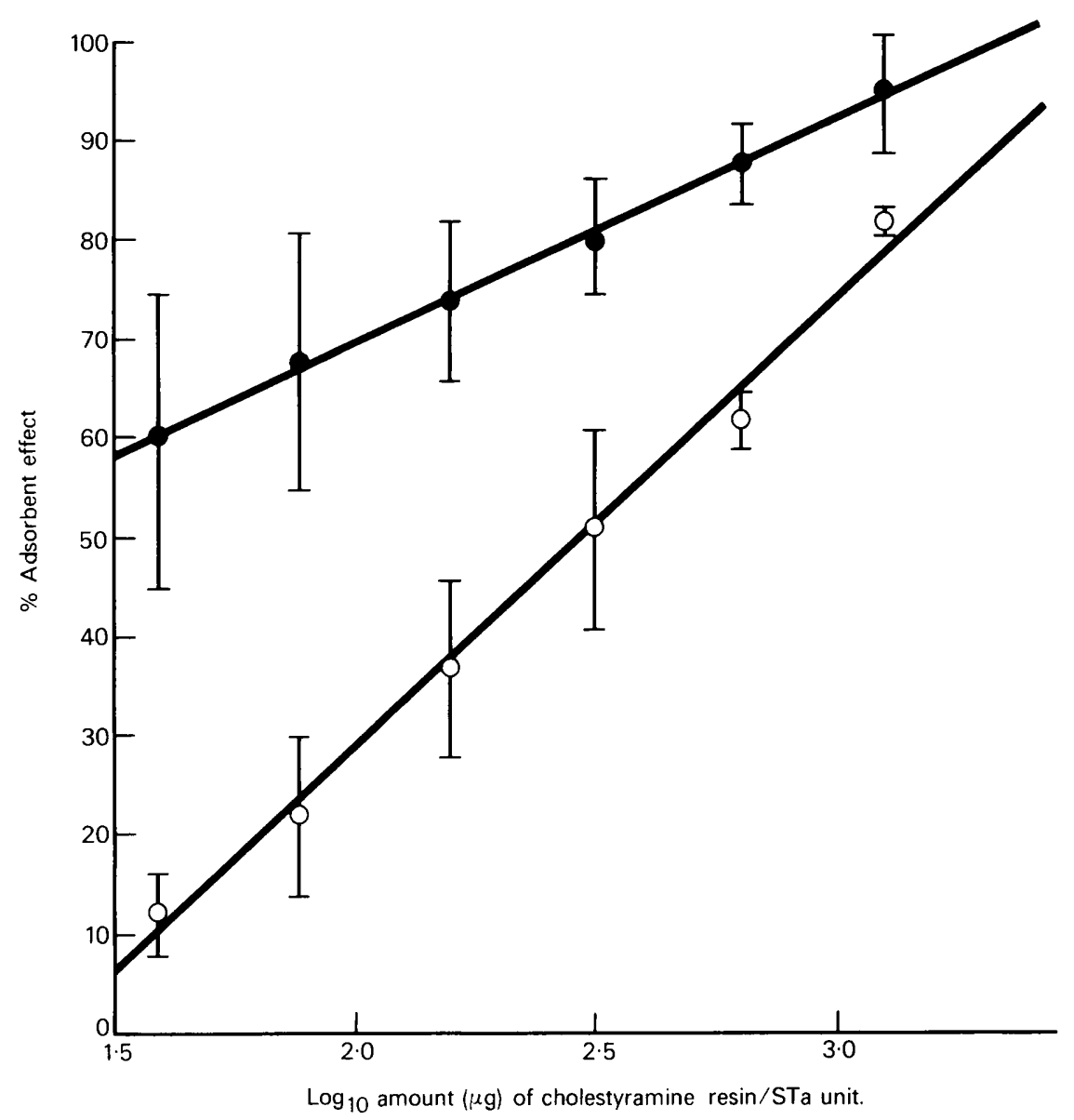

FIGURE.-Capacity of cholestyramine resin to adsorb STa. $\bullet-$ Cholestyramine suspended in water; $\circ-0=$ cholestyramine suspended in sow's milk. Each point represents the mean \pm S.E.M.

\section{TABLE III}

Fluid secretion in pig ligated intestinal loops treated with either STb, LT, or E. coli strain P16, with and without cholestyramine resin

\begin{tabular}{l|ccc}
\hline $\begin{array}{l}\text { Loop } \begin{array}{c}\text { Loated } \\
\text { with }\end{array} \\
\text { wean }\end{array}$ & \multicolumn{2}{|c}{ Volume : length ratio(mean \pm SEM) of } & \\
\cline { 2 - 3 } control loops & resin-treated loops & Significance* (p) \\
\hline STb & $1.65 \pm 0.36(11)$ & $0.44 \pm 0.16(11)$ & $<0.005$ \\
LT & $4.30 \pm 1.02(12)$ & $1.54 \pm 0.55(12)$ & $<0.001$ \\
E. coli & $2.24 \pm 0.31(17)$ & $1.29 \pm 0.13(17)$ & $<0.005$ \\
\hline
\end{tabular}

* Paired $t$ test.

Figures in parenthesis indicate number of loops inoculated. 
TABLE IV Effect of cholestyramine given orally with STa to piglets

\begin{tabular}{l|cc}
\hline \multicolumn{1}{c|}{ Treatment } & $\begin{array}{c}\text { Number of animals } \\
\text { with diarrhoea/total } \\
\text { number }\end{array}$ & $\begin{array}{c}\text { Diarrhoea score* } \\
\text { (mean } \pm \text { SEM) }\end{array}$ \\
\hline $\begin{array}{c}\text { STa (400 units) } \\
\text { STa (400 units) } \\
+2 \mathrm{~g}\end{array}$ & $7 / 7$ & $2 \cdot 0 \pm 0.4$ \\
cholestyramine & $2 / 7$ & $0.5 \pm 0.2 \dagger$ \\
\hline
\end{tabular}

* The diarrhoea of each animal was assessed on a 0-3 scale every hour for $7 \mathrm{~h}$ and a mean scour score for the group determined from the ratio of summed diarrhoeal scores to total number of observations.

+ Significant reduction as determined by Student's $t$ test $(\mathrm{p}<0.01)$.

\section{Effect of cholestyramine alone on E. coli-induced diarrhoea in piglets}

After the commencement of diarrhoea, pigs were given either $1 \mathrm{~g}$ or $0.5 \mathrm{~g}$ of resin twice daily as shown in table $\mathrm{V}$. Comparison with control piglets showed that neither treatment significantly affected the duration of diarrhoea. Moreover, treated animals gained weight more slowly than untreated controls $(\mathrm{p}<0.01)$.

\section{TABLE V}

Effect of cholestyramine resin on piglets infected with $E$. coli strain P155

\begin{tabular}{l|cccr}
\hline \multicolumn{1}{c|}{ Treatment } & $\begin{array}{c}\text { Number } \\
\text { of } \\
\text { piglets }\end{array}$ & $\begin{array}{c}\text { Duration of diarrhoea } \\
\text { (days) in } \\
\text { survivors } \\
\text { (mean } \pm \text { SEM) }\end{array}$ & $\begin{array}{c}\text { Weight } \\
\text { gain (\%) } \\
\text { (mean } \pm \text { SEM) }\end{array}$ & $\begin{array}{c}\text { Mortality } \\
(\%)\end{array}$ \\
\hline Controls & 9 & $2 \cdot 8 \pm 0.6$ & $88 \pm 13$ & 11 \\
Cholestyramine & 11 & $3 \cdot 2 \pm 0.3$ & $37 \pm 9^{*}$ & 9 \\
$\begin{array}{l}\quad \text { Ch, twice daily } \\
\quad 0.5 \text { g, twice daily }\end{array}$ & 9 & $3 \cdot 7 \pm 0.6$ & $45 \pm 6$ & 22 \\
\hline
\end{tabular}

* Significantly less than controls $(\mathrm{p}<0.01)$ by analysis of variance.

TABLE VI

Effect of cholestyramine resin and antibiotic therapy in piglets infected with E. coli strain P155

\begin{tabular}{l|ccccc}
\hline \multicolumn{1}{c|}{ Treatment* } & $\begin{array}{c}\text { Number } \\
\text { of } \\
\text { pislets }\end{array}$ & $\begin{array}{c}\text { Duration of } \\
\text { diarrhoea (days) } \\
\text { in survivors } \\
\text { (mean } \pm \text { SEM) }\end{array}$ & $\begin{array}{c}\text { Diarrhoea score } \\
\text { in survivors } \\
\text { (mean } \pm \text { SEM) }\end{array}$ & $\begin{array}{c}\text { Weight } \\
\text { gain (\%) } \\
\text { (mean } \pm \text { SEM) }\end{array}$ & $\begin{array}{c}\text { Mortality } \\
(\%)\end{array}$ \\
\hline $\begin{array}{c}\text { Controls } \\
\text { Amoxycillin }\end{array}$ & 16 & $5 \cdot 0 \pm 0 \cdot 5$ & $1 \cdot 0 \pm 0 \cdot 2$ & $93 \pm 7$ & 13 \\
$\begin{array}{c}\text { Amoxycillin }+ \\
\text { cholestyramine }\end{array}$ & 16 & $3 \cdot 8 \pm 0 \cdot 6$ & $0 \cdot 6 \pm 0 \cdot 1$ & $101 \pm 11$ & 0 \\
& 16 & $3.9 \pm 0 \cdot 7$ & $0 \cdot 8 \pm 0 \cdot 2$ & $56 \pm 10 \ddagger$ & 13 \\
\hline
\end{tabular}

* The resin was given in a dose of $1 \mathrm{~g}$ in $15 \mathrm{ml}$ water twice daily; amoxycillin was given in a dose of $40 \mathrm{mg}$ twice daily.

+ See footnote to table IV.

$\ddagger$ Significantly less than controls $(p<0.01)$ by analysis of variance. 
Effect of cholestyramine and amoxycillin on E. coli-induced diarrhoea in piglets

After the commencement of diarrhoea, pigs were given either cholestyramine resin ( $1 \mathrm{~g}$, twice daily) and amoxycillin ( $40 \mathrm{mg}$. twice daily), or amoxycillin alone (40 mg, twice daily). Table VI shows that amoxycillin reduced the amount and duration of diarrhoea. Animals receiving cholestyramine resin as an adjunct to antibiotic therapy showed no additional advantage. Piglets that received both cholestyramine and amoxycillin gained weight more slowly than amoxycillin-treated piglets or untreated controls $(\mathrm{p}<0.01)$.

Intestinal distribution and adsorptive capacity of cholestyramine in piglets with E. coli-induced diarrhoea

The failure of cholestyramine resin to produce a curative effect might have been caused by (1) retention in the stomach as a result of stasis, or (2) insufficient adsorptive capacity of the resin in the intestine.

Scouring piglets were given amoxycillin ( $40 \mathrm{mg}$, twice daily) and cholestyramine ( $1 \mathrm{~g}$, twice daily) for 3 days; the amount of resin in the intestines was then determined. Table VII shows that sodium hydroxide-insoluble material (cholestyramine) was not present in the small intestine, but significant amounts were present in the stomach and large intestine.

TABLE VII

Sodium hydroxide-insoluble material (cholestyramine resin) present in intestines of cholestyramine-treated diarrhoeic piglets, and its capacity to bind STa

\begin{tabular}{|c|c|c|}
\hline $\begin{array}{l}\text { Samples removed } \\
\text { from }\end{array}$ & $\begin{array}{c}\text { Amount of } \\
\text { resin recovered* } \\
(\text { mean } \pm \text { SEM })\end{array}$ & $\begin{array}{l}\text { Residual adsorbent } \\
\text { effect }(\%) \dagger\end{array}$ \\
\hline $\begin{array}{l}\text { stomach } \\
\text { small intestine } \\
\text { large intestine }\end{array}$ & $\begin{array}{l}1.23 \pm 0.16 \pm \\
0.00 \pm 0.03 \\
0.64 \pm 0.09 \ddagger\end{array}$ & $\begin{array}{l}0 \\
\cdots \\
1\end{array}$ \\
\hline
\end{tabular}

* Adjusted to take account of the values obtained in animals that did not receive resin

† Compared with that of a similar quantity of fresh resin mixed with an equal quantity of STa ( 1 unit).

$\ddagger$ Significant amounts of resin present by Student's $t$ test $(p=0.001)$.

Portions of the gastric and intestinal samples were mixed with STa and centrifuged. The supernates were then administered to infant mice to determine the percentage adsorbent activity remaining. Table VII shows that the samples from the resin-treated animals had no residual adsorbent effect.

Interference by milk with the adsorption of STa by cholestyramine

The figure shows that sow's milk significantly interfered with the capacity of cholestyramine to bind STa in vitro $(\mathrm{p}<0.001$, paired $t$ test). 


\section{DisCUSSION}

The use of colloidal clays in the treatment of gastrointestinal disturbances has been based on the belief that adsorption of bacteria or bacterial toxins or both occurs (Martin, 1955); activated attapulgite was reported to be superior to kaolin (Barr and Arnista, 1957). This belief is supported by little evidence, apart from in-vitro observations.

Nalin and Cash (1970), in a study made with Thiry-Vella loops in the intestine of dogs, found that kaolin, put into the loops before or with cholera toxin, protected the loops against the toxin; kaolin had no effect on the duration or volume of diarrhoea in cholera patients.

Gyles and Zigler (1978) reported that $10 \%$ colloidal attapulgite and $25 \%$ Pepto-Bismol (a commercial preparation containing bismuth subsalicylate) reduced the accumulation of fluid in pig ligated intestinal segments infected with enteropathogenic $E$. coli. Drucker et al. (1977) found that colloidal attapulgite reduced the fluid accumulation caused by LT and cholera toxin in rabbit ligated intestinal segments, but only when the toxin and attapulgite $(10 \%)$ were incubated before injection. Unlike Gyles and Zigler (1978) they were unable to show that attapulgite had any effect in loops inoculated with viable $E$. coli producing LT.

Ericsson et al. (1977) showed that pretreatment of rabbit ligated intestinal loops with Pepto-Bismol significantly reduced the fluid accumulation caused by crude $E$. coli and cholera toxins; the preparation had no effect when given after toxin administration. The active ingredient, bismuth subsalicylate, was further evaluated by DuPont et al. (1977), who showed it to be effective in the treatment of diarrhoea.

In the present study neither kaolin nor activated attapulgite adsorbed STa secreted by strains of E. coli enteropathogenic for piglets. Kohler (1971) noted that neither ST-as assayed in neonatal piglets, hence STa-nor LT were adsorbed to kaolin; he also found that enterotoxic activity (STa) was adsorbed by a cation- and an anion-exchange resin. These observations have been confirmed and extended in this report. In addition we have noted that STa was adsorbed by the macroreticular resin XAD-2, a non-ionic resin designed for the adsorption of water-soluble organic substances. This suggests that STa is lipophilic and amphoteric. We found that the most effective adsorbent for STa was the strong anion-exchange resin, cholestyramine; it also showed significant activity against STb, LT and $E$. coli in pig ligated intestinal loops.

Berant, Wagner and Cohen (1976) have reported cholestyramine to be effective in infantile diarrhoea of infectious origin, the diarrhoea ceasing within 1-3 days of treatment. Cholestyramine appeared to alleviate the symptoms in antibiotic-associated colitis associated with lincomycin and clindamycin therapy (Burbige and Milligan, 1975). This disease is now believed to be caused by toxin-producing strains of Clostridium difficile (Bartlett et al., 1978). Chang, Onderdonk and Bartlett (1978) showed that cholestyramine adsorbed the toxin produced by such strains; this might explain the remission of symptoms noted by Burbige and Milligan (1975). Chang et al. (1978) mentioned that 
$E$. coli enterotoxins were not adsorbed by cholestyramine, an observation contrary to our own.

In this study cholestyramine was found to bind STa in vitro and STa, STb and LT in vivo. In infant mice the fluid secretion that rapidly followed challenge with STa was significantly reduced. Cholestyramine also significantly reduced the fluid secretion in pig ligated intestinal loops after exposure to either STb, or LT, or viable organisms. When cholestyramine was mixed with STa and administered orally to piglets aged 2 days, diarrhoea was reduced.

However, the crucial test was to examine the effectiveness of cholestyramine in the treatment of diarrhoeic piglets after infection with viable enteropathogenic $E$. coli. The results were disappointing. No beneficial effect was noted when doses of $1 \mathrm{~g}$ or $0.5 \mathrm{~g}$ of resin twice daily, either alone or in conjunction with an antibiotic, were administered to diarrhoeic piglets. Indeed, resin-treated animals gained weight significantly more slowly than controls. Resin could still be recovered from the stomach and large intestine at necropsy, but resin could not be recovered from the small intestine where the toxins are believed to exert their biological effect. The capacity of the recovered material to react with STa after passage through the stomach was significantly reduced, probably due to saturation with some constituents of the sow's milk. The reduced ability of cholestyramine to adsorb STa in the presence of sow's milk was demonstrated in vitro. The binding of essential nutrients or bile salts to the resin might explain the effect on weight gain in these animals.

These results do not encourage the use of cholestyramine in the treatment of diarrhoea in unweaned piglets. Its possible value in weaned piglets or in other species remains to be determined.

\section{SUMMARY}

Several adsorbent materials were evaluated for their ability to bind Escherichia coli enterotoxins. Cholestyramine, a strong anion-exchange resin, bound the heat-labile and the heat-stable types of enterotoxin and reduced significantly their effects in some animal models. However, its efficacy in the treatment of diarrhoeic piglets ppeared to be adversely affected by the presence of milk in the alimentary tract.

We thank C. Cowley, P. Diprose and P. Whittington for excellent technical assistance, and Mrs E. T. Gaskin for excellent secretarial services.

\section{REFERENCES}

BARR, M. AND ARnista, E. J. 1957. Adsorption studies on clays III. The adsorption of diphtheria toxin by activated attapulgites, halloysite and kaolin. J. Am. pharm. Ass., 46, 493.

Bartlett, J. G., Chang, T. W., Gurwith, M., Gorbach, S. L. and Onderdonk, A. B. 1978. Antibiotic-associated pseudomembranous colitis due to toxin producing clostridia. New Eng. J. Med., 298, 531 . 
Berant, M., Wagner Y. And Cohen, N. 1976. Cholestyramine in the management of infantile diarrhoea. J. Pediat., 88, 153.

Burbige, E. J. ANd Milligan, F. D. 1975. Pseudomembranous colitis. Association with antibiotics and therapy with cholestyramine. J. Am. med. Ass., 231, 1157.

Burgess, M. N., Bywater, R. J., Cowley, C. M., Mullan, N. A. and Newsome, P. M. 1978. Biological evaluation of a methanol-soluble, heat-stable $E$. coli enterotoxin in infant mice, pigs, rabbits and calves. Infect. Immun., 21, 526.

Burgess, M. N., Cowley, C. M., Melling, J., Mullan, N. A. and Newsome, P. M. 1979. Assay of the heat-labile enterotoxin of Escherichia coli in infant rabbits. J. med. Microbiol.,12, 291.

Chang, T. W., Onderdonk, A. B. and Bartlett, J. G. 1978. Anion exchange resins in antibiotic-associated colitis. Lancet, 2, 258.

Dean, A. G., Ching, Y. C., Williams, R. G. And Harden, L. B. 1972. Test for Escherichia coli enterotoxin using infant mice: application in a study of diarrhea in children in Honolulu. J. infect. Dis., 125, 407.

DruCKer, M. M., Ogra, P. L., Goldhar, J. AND Neter, E. 1977. The effect of attapulgite and charcoal on enterotoxicity of Vibrio cholerae and Escherichia coli enterotoxins in rabbits. Infection, 5, 211.

DuPont, H. L., Sullivan, P., Pickering, L. K., Haynes, G. and Ackerman, M. S. 1977. Symptomatic treatment of diarrhoea with bismuth subsalicylate among students attending a Mexican University. Gastroenterology, 73, 715.

Ericsson, C. D., Evans, D. G., DuPont, H. L., Evans, D. J. and Pickering, L. K. 1977. Bismuth subsalicylate inhibits activity of crude toxins of Escherichia coli and Vibrio cholerae. J. infect. Dis., 136, 693.

Gyles, C. L. AND ZigleR, M. 1978. The effect of adsorbent and anti-inflammatory drugs on secretion in ligated segments of pig intestine infected with Escherichia coli. Can. J. comp. Med., 42, 260.

KOHLER, E. M. 1968. Enterotoxic activity of filtrates of Escherichia coli in young pigs. Am.J. vet. Res., 29, 2263.

KoHLER, E. M. 1971. Enterotoxic activity of whole cell lysates of E. coli in young pigs. Am.J. vet. Res., 32, 731 .

MARTIN, G. J. 1955. Ion-exchange and adsorption agents in medicine: the concept of intestinal bionomics, London.

Mitchell, I. DE G., TAME, M. J. AND Kenworthy, R. 1974. Conditions for the production of Escherichia coli enterotoxin in a defined medium. J. med. Microbiol., 7, 395.

Mullan, N. A., Burgess, M. N. AND Newsome, P. M. 1978. Characterisation of a partially purified, methanol-soluble, heat-stable Escherichia coli enterotoxin in infant mice. Infect. Immun., 19, 779.

Nalin, D. R. ANd Cash, R. A. 1970. Kaolin and cholera. J. Pakistan med. Ass., 20, 177.

Smith, H. W. AND Gyles, C. L. 1970. The relationship between two apparently different enterotoxins produced by enteropathogenic strains of $E$. coli of porcine origin. J. med. Microbiol., 3, 403.

Smith, H. W. and Halls, S. 1967. Observations by the ligated intestinal segment and oral inoculation methods on $E$. coli infections in pigs, calves, lambs and rabbits. J. Path. Bact., 93, 499. 